\title{
Utility of Platelet Function Testing in Cardiac Surgery in 2021
}

\author{
Klaus Görlinger ${ }^{1,2, \odot}$ Ajay Gandhi ${ }^{3, \odot}$ \\ ${ }^{1}$ Department of Anaesthesiology and Intensive Care Medicine, \\ University Hospital Essen, University Duisburg-Essen, Essen, \\ Germany \\ 2Medical Affairs, TEM Innovations GmbH, Munich, Germany \\ ${ }^{3}$ Clinical Affairs, Werfen, New Delhi, India528487
}

J Card Crit Care 2021;5:84-87.

In this issue of the Journal of Cardiac Critical Care, Sharan et al and Datta et al are reporting on perioperative and peri-interventional platelet function testing in an attempt to implement personalized antiplatelet therapy in India. ${ }^{1,2}$

Sharan et al demonstrated that algorithm-based point-of-care thromboelastometry (ROTEM delta) combined with whole blood aggregometry (ROTEM platelet) helped to guide hemostatic interventions in the intra- and postoperative period of cardiac surgery. ${ }^{1} \mathrm{On}$ the one hand, this can avoid inappropriate blood transfusion, and on the other hand, excessive bleeding during and after cardiac surgery. ${ }^{3,4}$ Both bleeding and transfusion are associated with worse patient outcomes. ${ }^{5}$ Here, whole blood impedance aggregometry (multiplate or ROTEM platelet) has been shown to be a valuable tool to assess platelet function before, during, and after cardiovascular surgery as well as during extracorporeal membrane oxygenation (ECMO). ${ }^{6-20}$ This applies for pediatric cardiac surgery and ECMO too ( $\boldsymbol{\sim}$ Fig. 1 and $\boldsymbol{\sim}$ Table $\mathbf{1}){ }^{21-23}$ Furthermore, platelet function testing has been shown to predict patients' outcome in trauma, bacterial sepsis, and COVID-19. ${ }^{24-26}$ In contrast to drug monitoring of aspirin and P2Y12-receptor inhibitors with arachidonic acid (ASPI test or ARATEM) and adenosine diphosphate (ADP; ADP test or ADP test) activated assays, platelet dysfunction due to diseases (e.g., trauma, cirrhosis, and sepsis) and devices (e.g., cardiopulmonary bypass, ECMO and dialysis) seem to affect predominantly the ADPand thrombin-pathway (TRAP test or TRAPTEM activated by thrombin-receptor activating peptide 6; TRAP6). Here, a drop in platelet function has to be considered as a biomarker for worse outcome and not as trigger for platelet transfusion. Accordingly, Sharan et al demonstrated that a significant drop in platelet function from postprotamine to 48 hours after surgery in the ICU was associated with adverse fatal

published online

August 5, 2021
DOI https://doi.org/

$10.1055 / \mathrm{s}-0041-1732839$

ISSN 2457-0206

\begin{abstract}
Address for correspondence Klaus Görlinger, MD, Department of Anaesthesiology and Intensive Care Medicine, University Hospital Essen, University Duisburg-Essen, Essen, Germany (e-mail: kgoerlinger@ilww.com).
\end{abstract}

outcome, with an area under the aggregation curve (AUC) threshold value for TRAPTEM, ADPTEM and ARATEM of 53, 43 and $49.5 \Omega \cdot \min$, respectively. ${ }^{1}$ This is in line with the results reported by Yassen et al, in that a significant decrease in TRAPTEM AUC between postoperative day 14 and 21 after liver transplantation is associated with increased 3-month nonsurvival. ${ }^{27}$ On the other hand, increased aspirin resistance after cardiac surgery can be associated with ischemic events. This increase aspirin resistance seems to be mediated by an increased turnover of platelets after cardiac surgery rather than due to a pharmacologic aspirin resistance. Therefore, a switch to dual antiplatelet therapy should be considered in patients with postoperative aspirin resistance to avoid ischemic events..$^{28,29}$

Datta et al reported on the use of thromboelastography platelet mapping for the assessment of individual platelet response secondary to oral antiplatelet therapy after percutaneous coronary interventions as an attempt to implement personalized antiplatelet therapy in India. ${ }^{2}$ Here, the authors demonstrated that aspirin along with ticagrelor was associated with a higher mean percentage of platelet inhibition and lower high on-treatment platelet reactivity (HPR) as compared with the usage of aspirin combined with clopidogrel or prasugrel. They concluded that platelet function testing may be used effectively to measure the individual response to antiplatelet therapy and personalize antiplatelet therapy for cardiac patients. This is in line with other studies dealing with personalized antiplatelet therapy in cardiology patients. ${ }^{30-32}$ In particular, the use of platelet function testing to deescalate antiplatelet therapy and avoid bleeding complications in hyperresponders seems to be a reasonable and promising approach. ${ }^{33,34}$ Furthermore, platelet function test might be helpful to determine the optimum timing of elective and urgent coronary artery bypass graft (CABG) surgery (c) 2021. Official Publication of The Simulation Society (TSS), accredited by International Society of Cardiovascular Ultrasound (ISCU).

This is an open access article published by Thieme under the terms of the Creative Commons Attribution-NonDerivative-NonCommercial-License, permitting copying and reproduction so long as the original work is given appropriate credit. Contents may not be used for commercial purposes, or adapted, remixed, transformed or built upon. (https://creativecommons.org/licenses/by-nc-nd/4.0/). Thieme Medical and Scientific Publishers Pvt. Ltd. A-12, 2nd Floor, Sector 2, Noida-201301 UP, India 
Table 1 Fibrinogen dose calculation

\begin{tabular}{|l|l|l|l|}
\hline $\begin{array}{l}\text { Targeted increase in } \mathrm{A5}_{\mathrm{FlB}} \\
(\mathrm{mm})\end{array}$ & $\begin{array}{l}\text { Fibrinogen dose } \\
\text { (mg/kg body weight) }\end{array}$ & $\begin{array}{l}\text { Fibrinogen concentrate } \\
\text { (mL/kg body weight) }\end{array}$ & $\begin{array}{l}\text { Cryoprecipitate } \\
\text { (mL/kg body weight) }\end{array}$ \\
\hline $2 \mathrm{~mm}$ & $12.5 \mathrm{mg} / \mathrm{kg} \mathrm{bw}$ & $0.6 \mathrm{~mL} / \mathrm{kg} \mathrm{bw}$ & $1 \mathrm{~mL} / \mathrm{kg} \mathrm{bw}$ \\
\hline $4 \mathrm{~mm}$ & $25.0 \mathrm{mg} / \mathrm{kg} \mathrm{bw}$ & $1.2 \mathrm{~mL} / \mathrm{kg} \mathrm{bw}$ & $2 \mathrm{~mL} / \mathrm{kg} \mathrm{bw}$ \\
\hline $6 \mathrm{~mm}$ & $37.5 \mathrm{mg} / \mathrm{kg} \mathrm{bw}$ & $1.9 \mathrm{~mL} / \mathrm{kg} \mathrm{bw}$ & $3 \mathrm{~mL} / \mathrm{kg} \mathrm{bw}$ \\
\hline $8 \mathrm{~mm}$ & $50.0 \mathrm{mg} / \mathrm{kg} \mathrm{bw}$ & $2.5 \mathrm{~mL} / \mathrm{kg} \mathrm{bw}$ & $4 \mathrm{~mL} / \mathrm{kg} \mathrm{bw}$ \\
\hline $10 \mathrm{~mm}$ & $62.5 \mathrm{mg} / \mathrm{kg} \mathrm{bw}$ & $3.1 \mathrm{~mL} / \mathrm{kg} \mathrm{bw}$ & $5 \mathrm{~mL} / \mathrm{kg} \mathrm{bw}$ \\
\hline $12 \mathrm{~mm}$ & $75.0 \mathrm{mg} / \mathrm{kg} \mathrm{bw}$ & $3.8 \mathrm{~mL} / \mathrm{kg} \mathrm{bw}$ & $6 \mathrm{~mL} / \mathrm{kg} \mathrm{bw}$ \\
\hline
\end{tabular}

Fibrinogen dose $(\mathrm{g})=$ targeted increase in $\mathrm{A} 5_{\mathrm{FB}}(\mathrm{mm}) \times$ body weight $(\mathrm{kg}) / 160$.

Correction factor $\left(140-160 \mathrm{~mm} \cdot \mathrm{kg} \cdot \mathrm{g}^{-1}\right)$ depends on the actual plasma volume.

$\mathrm{A} 5_{\mathrm{FIB}}$ levels of 12 to $16 \mathrm{~mm}$ may compensate for low platelet count or function.

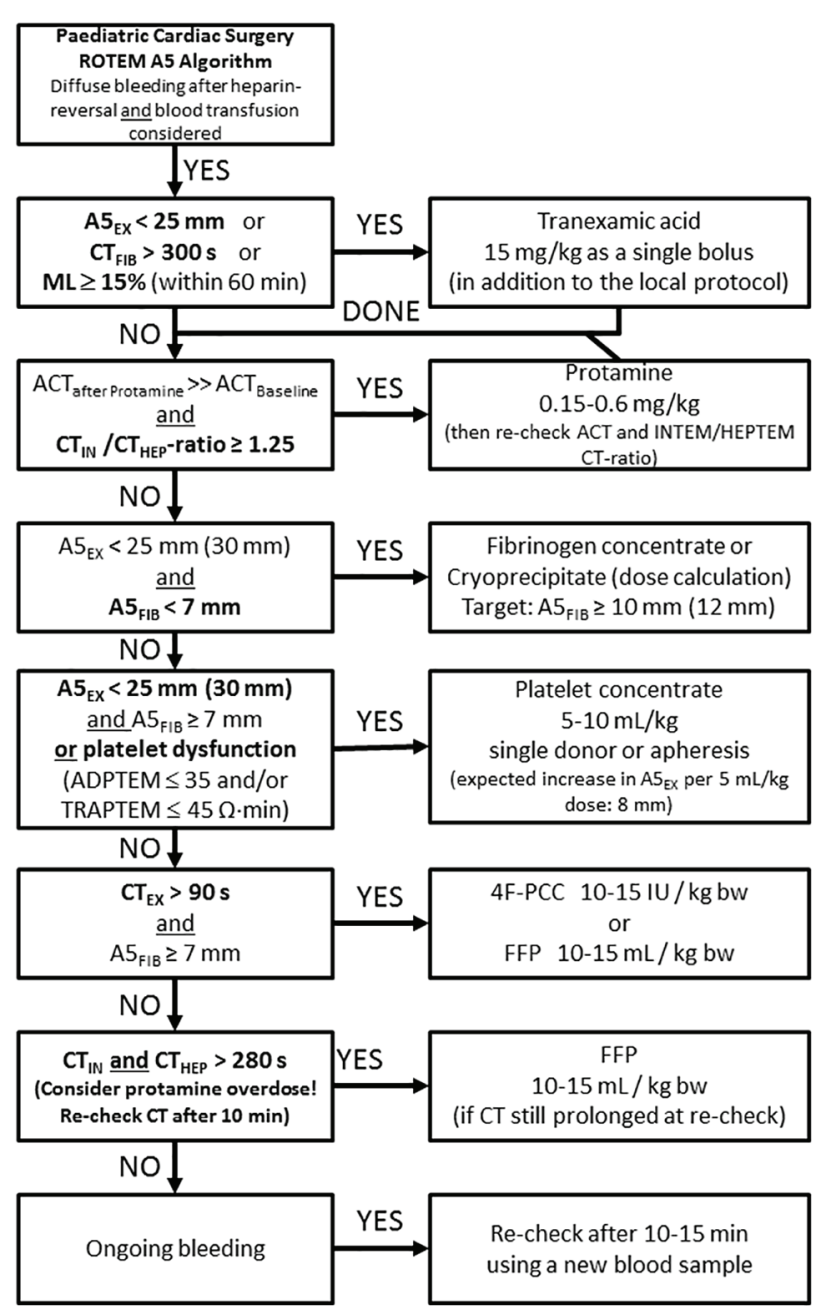

Fig. 1 Evidence-based pediatric cardiac surgery ROTEM A5 algorithm. Abbreviations: 4F-PCC, 4-factor prothrombin complex concentrate; $A 5_{E X}$, EXTEM clot firmness amplitude 5 minutes after $C T$ in $\mathrm{mm}$; $\mathrm{A} 5{ }_{\mathrm{FI}}$, FIBTEM clot firmness amplitude 5 minutes after $\mathrm{CT}$ in $\mathrm{mm}$; $\mathrm{ACT}$, activated clotting time in seconds; $\mathrm{CT}_{\mathrm{FII}}$, FIBTEM coagulation time in seconds; $\mathrm{CT}_{\text {HEP }}$, HEPTEM coagulation time in seconds; $\mathrm{CT}_{\text {IN }}$, INTEM coagulation time in seconds; EXTEM, extrinsic ROTEM assay activated by tissue factor and heparin neutralization by polybrene; FFP, fresh frozen plasma; FIBTEM, extrinsic ROTEM assay with platelet inhibition by cytochalasin D and heparin neutralization by polybrene; HEPTEM, intrinsic ROTEM assay with heparin neutralization by heparinase; INTEM, intrinsic ROTEM assay activated by ellagic acid; MCF, maximum clot firmness in mm; ML, EXTEM or FIBTEM maximum lysis in \% of MCF; ROTEM, rotational thromboelastometry (Courtesy of Klaus Görlinger, Essen, Germany). after P2Y12 inhibitor cessation, in order to minimize bleeding complications. ${ }^{35-42}$

In summary, both platelet function testing studies published in this issue of the Journal of Cardiac Critical Care support the use of peri-interventional and perioperative platelet function testing and highlight its potential to personalize and optimize the management of antiplatelet drugs in terms of precision medicine by implementing the therapeutic window concept. ${ }^{43-47}$ This approach is also recommended in European and American guidelines, and the time is ripe to implement personalized antiplatelet therapy and bleeding management as an essential part of patient blood management in India. ${ }^{48-50}$

AG is the Associate Director of Clinical Affairs of Werfen India, New Delhi, India.

\section{Conflict of Interest}

KG is the Medical Director of Tem Innovations $\mathrm{GmbH}$, Munich, Germany.

\section{References}

1 Sharan S, Kapoor PM, Devagourou V. Role of platelet function test in predicting postoperative bleeding risk after coronary artery bypass grafting: a prospective observational study. J Card Crit Care TSS 2021;(e-pub ahead of print) doi: 10.1055/s-0041-1728978

2 Datta SS, De D, Muslim NA. Use of thromboelastography platelet mapping for assessment of individual platelet response secondary to oral antiplatelet therapy after percutaneous coronary intervention: an attempt to start personalized antiplatelet therapy in India. J Card Crit Care TSS 2021;(e-pub ahead of print). doi: 10.1055s/0041-1724225

3 Görlinger K, Dirkmann D, Hanke AA, et al. First-line therapy with coagulation factor concentrates combined with pointof-care coagulation testing is associated with decreased allogeneic blood transfusion in cardiovascular surgery: a retrospective, single-center cohort study. Anesthesiology 2011;115(6):1179-1191

4 Weber CF, Görlinger K, Meininger D, et al. Point-of-care testing: a prospective, randomized clinical trial of efficacy in coagulopathic cardiac surgery patients. Anesthesiology 2012;117(3):531-547

5 Ranucci M, Baryshnikova E, Castelvecchio S, Pelissero G; Surgical and Clinical Outcome Research (SCORE) Group. Major bleeding, transfusions, and anemia: the deadly triad of cardiac surgery. Ann Thorac Surg 2013;96(2):478-485

6 Görlinger K, Jambor C, Hanke AA, et al. Perioperative coagulation management and control of platelet transfusion by point-of-care platelet function analysis. Transfus Med Hemother 2007;34(6):396-411 
7 Görlinger K, Jambor C, Dirkmann D, et al. [Platelet function analysis with point-of-care methods]. Herz 2008;33(4):297-305

8 Corredor C, Wasowicz M, Karkouti K, Sharma V. The role of point-of-care platelet function testing in predicting postoperative bleeding following cardiac surgery: a systematic review and meta-analysis. Anaesthesia 2015;70(6):715-731

9 Petricevic M, Konosic S, Biocina B, et al. Bleeding risk assessment in patients undergoing elective cardiac surgery using ROTEM platelet and Multiplate impedance aggregometry. Anaesthesia 2016;71(6):636-647

10 Malm CJ, Hansson EC, Åkesson J, et al. Preoperative platelet function predicts perioperative bleeding complications in ticagrelor-treated cardiac surgery patients: a prospective observational study. Br J Anaesth 2016;117(3):309-315

11 Björklund E, Hansson EC, Romlin BS, Jeppsson A, Malm CJ. Postoperative platelet function is associated with severe bleeding in ticagrelor-treated patients. Interact Cardiovasc Thorac Surg 2019;28(5):709-715

12 Ranucci M, Pistuddi V, Di Dedda U, Menicanti L, De Vincentiis C, Baryshnikova E. Platelet function after cardiac surgery and its association with severe postoperative bleeding: the PLATFORM study. Platelets 2019;30(7):908-914

13 Petricevic M, Knezevic J, Biocina B, et al. Association among clopidogrel cessation, platelet function, and bleeding in coronary bypass surgery: an observational trial. Thorac Thorac Cardiovasc Surg 2019;(e-pub ahead of print). doi: $10.1055 / \mathrm{s}-0039-1693122$

14 Kjellberg G, Holm M, Lindvall G. Gryfelt G, van der Linden J, Wikman A. Platelet function analysed by ROTEM platelet in cardiac surgery after cardiopulmonary bypass and platelet transfusion. Transfus Med 2020;30(5):369-376

15 Petricevic M, Petricevic M, Piljic D, Rotim K. The association between perioperative point-of-care platelet function analyses and transfusion requirements in cardiac surgery: methodological considerations. Thorac Cardiovasc Surg 2021;e-pub ahead of print). doi: 10.1055/s-0040-1716325

16 Petricevic M, Petricevic M, Pasalic M, et al. Bleeding risk stratification in coronary artery surgery: the should-not-bleed score. J Cardiothorac Surg 2021;16(1):103

17 Nair P, Hoechter DJ, Buscher H, et al. Prospective observational study of hemostatic alterations during adult extracorporeal membrane oxygenation (ECMO) using point-of-care thromboelastometry and platelet aggregometry. J Cardiothorac Vasc Anesth 2015;29(2):288-296

18 Tauber H, Streif W, Fritz J, et al. Predicting transfusion requirements during extracorporeal membrane oxygenation. J Cardiothorac Vasc Anesth 2016;30(3):692-701

19 Laine A, Niemi T, Suojaranta-Ylinen R, et al. Decreased maximum clot firmness in rotational thromboelastometry (ROTEM) is associated with bleeding during extracorporeal mechanical circulatory support. Perfusion 2016;31(8):625-633

20 Balle CM, Jeppesen AN, Christensen S, Hvas AM. platelet function during extracorporeal membrane oxygenation in adult patients. Front Cardiovasc Med 2019;6:114

21 Romlin BS, Söderlund F, Wåhlander H, Nilsson B, Baghaei F, Jeppsson A. Platelet count and function in paediatric cardiac surgery: a prospective observational study. $\mathrm{Br}$ J Anaesth 2014;113(5):847-854

22 Romlin BS, Söderlund F, Wåhlander H, et al. Perioperative monitoring of platelet function in paediatric cardiac surgery by thromboelastometry, or platelet aggregometry? $\mathrm{Br}$ J Anaesth 2016;116(6):822-828

23 Kapoor PM, Karanjkar A, Bhardwaj V. Evaluation of coagulopathy on veno-arterial ECMO (VA) extracorporeal membrane oxygenation using platelet aggregometry and standard tests: A narrative review. Egyptian J Crit Care Med 2018;6:73-78

24 Chapman MP, Moore EE, Moore HB, et al. Early TRAP path-way platelet inhibition predicts coagulopathic hemorrhage in trauma. Shock 2015;43(6(Suppl 1):33
25 Adamzik M, Görlinger K, Peters J, Hartmann M. Whole blood impedance aggregometry as a biomarker for the diagnosis and prognosis of severe sepsis. Crit Care 2012;16(5):R204

26 Corrêa TD, Cordioli RL, Campos Guerra JC, et al. Coagulation profile of COVID-19 patients admitted to the ICU: An exploratory study. PLoS One 2020;15(12):e0243604

27 Yassen KA, Awad E, Refaat E, et al. A3162: Monitoring of platelet function during and three weeks after adult liver transplantation with ROTEM platelet and conventional coagulation tests. Anesthesiology 2018. Available at: http://www.asaabstracts. $\mathrm{com} /$ strands/asaabstracts/abstract.htm?year=2018\&index$=8$ \&absnum $=4522$. Accessed July 27, 2021

28 Petricevic M, Biocina B, Konosic S, Kopjar T, Kunac N, Gasparovic H. Assessment of platelet function by whole blood impedance aggregometry in coronary artery bypass grafting patients on acetylsalicylic acid treatment may prompt a switch to dual antiplatelet therapy. Heart Vessels 2013;28(1):57-65

29 Petricevic M, Kopjar T, Gasparovic H, et al. Impact of aspirin resistance on outcomes among patients following coronary artery bypass grafting: exploratory analysis from randomized controlled trial (NCT01159639. J Thromb Thrombolysis 2015;39(4):522-531

30 Siller-Matula JM, Gruber C, Francesconi M, et al. The net clinical benefit of personalized antiplatelet therapy in patients undergoing percutaneous coronary intervention. Clin Sci (Lond 2015;128(2):121-130

31 Zhang Y, Zhang P, Li Z, et al. Benefits of laboratory personalized antiplatelet therapy in patients undergoing percutaneous coronary intervention: a meta-analysis of randomized controlled trials. Cardiol J 2018;25(1):128-141

32 Fontana P, Roffi M, Reny JL. Platelet function test use for patients with coronary artery disease in the early 2020s. J Clin Med 2020;9(1):194

33 Stone GW, Witzenbichler B, Weisz G, et al. ADAPT-DES Investigators. Platelet reactivity and clinical outcomes after coronary artery implantation of drug-eluting stents (ADAPT-DES): a prospective multicentre registry study. Lancet 2013;382(9892):614-623

34 Sibbing D, Aradi D, Jacobshagen C, et al. TROPICAL-ACS Investigators. Guided de-escalation of antiplatelet treatment in patients with acute coronary syndrome undergoing percutaneous coronary intervention (TROPICAL-ACS): a randomised, open-label, multicentre trial. Lancet 2017;390(10104) :1747-1757

35 Ranucci M, Baryshnikova E, Soro G, Ballotta A, De Benedetti D, Conti D; Surgical and Clinical Outcome Research (SCORE) Group. Multiple electrode whole-blood aggregometry and bleeding in cardiac surgery patients receiving thienopyridines. Ann Thorac Surg 2011;91(1):123-129

36 Ranucci M, Colella D, Baryshnikova E, Di Dedda U; Surgical and Clinical Outcome Research (SCORE) Group. Effect of preoperative P2Y12 and thrombin platelet receptor inhibition on bleeding after cardiac surgery. Br J Anaesth 2014;113(6):970-976

37 Hansson EC, Malm CJ, Hesse C, et al. Platelet function recovery after ticagrelor withdrawal in patients awaiting urgent coronary surgery. Eur J Cardiothorac Surg 2017;51(4):633-637

38 Mahla E, Suarez TA, Bliden KP, et al. Platelet function measurement-based strategy to reduce bleeding and waiting time in clopidogrel-treated patients undergoing coronary artery bypass graft surgery: the timing based on platelet function strategy to reduce clopidogrel-associated bleeding related to CABG (TARGET-CABG) study. Circ Cardiovasc Interv 2012;5(2):261-269

39 Mahla E, Prueller F, Farzi S, et al. Does platelet reactivity predict bleeding in patients needing urgent coronary artery bypass grafting during dual antiplatelet therapy? Ann Thorac Surg 2016;102(6):2010-2017

40 Mahla E, Tantry US, Prüller F, Gurbel PA. Is there a role for preoperative platelet function testing in patients 
undergoing cardiac surgery during antiplatelet therapy? Circulation 2018;138(19):2145-2159

41 Bedeir K, Bliden K, Tantry U, Gurbel PA, Mahla E. Timing of coronary bypass surgery in patients receiving clopidogrel: the role of VerifyNow. Can J Cardiol 2016;32(6):724-725

42 Orvin K, Barac YD, Kornowski R, et al. Monitoring platelet reactivity during prasugrel or ticagrelor washout before urgent coronary artery bypass grafting. Coron Artery Dis 2017;28(6):465-471

43 Sibbing D, Steinhubl SR, Schulz S, Schömig A, Kastrati A. Platelet aggregation and its association with stent thrombosis and bleeding in clopidogrel-treated patients: initial evidence of a therapeutic window. J Am Coll Cardiol 2010;56(4):317-318

44 Tantry US, Jeong YH, Navarese EP, Gurbel PA. Platelet function measurement in elective percutaneous coronary intervention patients: exploring the concept of a P2Y12 inhibitor therapeutic window. JACC Cardiovasc Interv 2012;5(3):290-292

45 Malhotra N, Abunassar J, Wells GA, et al; Cardiovascular Percutaneous Intervention TriAL (CAPITAL) investigators. A pharmacodynamic comparison of a personalized strategy for anti-platelet therapy versus ticagrelor in achieving a therapeutic window. Int J Cardiol 2015;197:318-325

46 Petricevic M, Milicic D, White A, et al. Development of a concept for a personalized approach in the perioperative antiplatelet therapy administration/discontinuation management based on multiple electrode aggregometry in patients undergoing coronary artery surgery. J Thromb Thrombolysis 2015;40(3):383-391

47 Görlinger K, Pérez-Ferrer A, Dirkmann D, et al. The role of evidence-based algorithms for rotational thromboelastometry-guided bleeding management. Korean J Anesthesiol 2019;72(4):297-322

48 Kozek-Langenecker SA, Ahmed AB, Afshari A, et al. Management of severe perioperative bleeding: guidelines from the European Society of Anaesthesiology: First update 2016. Eur J Anaesthesiol 2017;34(6):332-395

49 Raphael J, Mazer CD, Subramani S, et al. Society of Cardiovascular Anesthesiologists Clinical Practice Improvement Advisory for Management of Perioperative Bleeding and Hemostasis in Cardiac Surgery Patients. Anesth Analg 2019;129(5):1209-1221

50 Gandhi A, Görlinger K, Nair SC, et al. Patient blood management in India - Review of current practices and feasibility of applying appropriate standard of care guidelines. A position paper by an interdisciplinary expert group. J Anaesthesiol Clin Pharmacol 2021;37(1):3-13 